\title{
Whole Grain Gluten-Free High Protein Vegetable Snacks of Buckwheat Peanut Meal and Kale*
}

\author{
Talwinder S. Kahlon, Roberto J. Avena-Bustillos, Mei-Chen M. Chiu \\ Western Regional Research Center, USDA-ARS, Albany, CA, USA \\ Email: Talwinder.Kahlon@ars.usda.gov
}

How to cite this paper: Kahlon, T.S., Avena-Bustillos, R.J. and Chiu, M.-C.M. (2018) Whole Grain Gluten-Free High Protein Vegetable Snacks of Buckwheat Peanut Meal and Kale. Food and Nutrition Sciences, 9, 335-345.

https://doi.org/10.4236/fns.2018.94026

Received: January 17, 2018

Accepted: April 23, 2018

Published: April 26, 2018

Copyright ( 92018 by authors and Scientific Research Publishing Inc. This work is licensed under the Creative Commons Attribution International License (CC BY 4.0).

http://creativecommons.org/licenses/by/4.0/

\begin{abstract}
Whole grain gluten-free high protein vegetable snacks were evaluated. The snacks were Buckwheat-Peanut Meal-Kale (BPK), BPK-Garlic, BPK-Onion and BPK-Ginger. Peanut meal was utilized to increase the protein content of these snacks as well as to add value to this agricultural byproduct. Snack dough was prepared using water nearly 1:1 as other as is ingredients. About 20 $\mathrm{g}$ of snack dough was placed on preheated KrumKake Express 839 Baker and cooked for 2 minutes. Sixty-nine in-house volunteers judged Color/Appearance and Texture/Mouth feel to be similar for the snacks tested. Taste/Flavor for BPK, BPK-Garlic and BPK-Onion snacks was similar and significantly higher $(p \leq 0.05)$ than for BPK-Ginger snacks. Odor/Aroma for BPK-Garlic snacks was significantly higher than for BPK-Ginger snacks. Acceptance for BPK and BPK-Garlic snacks was significantly higher than for BPK-Ginger snacks. Expansion $3.6-4.2$, porosity $0.72-0.75$ and water activity $0.35-0.38$ suggests that the snacks tested were light, crispy and have good anti-microbial stability. Acceptance was BPK and BPK-Garlic 94\%, BPK-Onion 86\% and BPK-Ginger $78 \%$. These snacks contained only 3 - 4 ingredients and could be made in any house hold kitchen and/or in commercial production. Acceptance of $78 \%$ $94 \%$ is very desirable. These whole grain gluten-free high protein vegetable healthy nutritious tasty snacks offer choice for all consumers, including individual's sensitive to gluten.
\end{abstract}

\section{Keywords}

Sensory Evaluation, Buckwheat, Kale, Peanut Meal, Gluten-Free, Water Activity

*USDA is an equal opportunity provider and employer. Mention of trade names or commercial products in this report is solely for the purpose of providing specific information and does not imply recommendation or endorsement by the U.S. Department of Agriculture. 


\section{Introduction}

Snacks play an important role in between meals. In all family and public events snacks are trendy for consumption. Young individuals prefer snacks over regular meals. The snacks are expected to be healthful, flavorful, easy to carry and with very desirable taste [1]. For children, snacks are extremely essential in school and in after school programs. Serving healthy snacks is important in providing good nutrition, supporting lifelong healthy eating habits, and would help in preventing costly and potentially-disabling diseases, such as heart disease, cancer, diabetes, high blood pressure, and obesity. Nutrition Policy and Promotion; Dietary Guidelines for Americans [2] recommends that, at least 1/2 of all the grains eaten should be whole grains. Average intakes of whole grains are far below recommended levels across all age-sex groups, and average intakes of refined grains are well above recommended limits for most age-sex groups. The Whole Grain Council [3] has documented that eating whole grains instead of refined grains lowers the risk of many chronic diseases. Helnaes et al. [4] reported that higher intake of whole grain rye and oats and not that of wheat was related to lower risk of heart disease in men and women. Wheat is the main grain of many snack products, however there is increasing evidence of hyper-sensitivity to gluten in the celiac patients. Hypersensitivity to gluten results in eroding of the lining of small intestines [5]. It results in delayed growth and many serious health problems. Healthy intestinal lining is required to absorb the needed nutrients. Food and Drug Administration [6] defines "gluten-free" with less than 20 parts per million, gluten. This is the level that can be validly tested and can be tolerated by most gluten sensitive individual. Hypersensitivity to gluten has been increasing worldwide. Some of the potential reasons could be use of microbial transaminase enzyme as animal protein glue to produce meat patties from meat scraps. Transamination of gluten could make it hypersensitive. Another reason could be that pollution and toxic environment has altered gut microbiome resulting in loss of gluten immunity. If one family member is gluten sensitive, the whole family must consume gluten-free foods. Snacks made of gluten-free whole grains would be desirable. Snacks available in US are essentially unhealthy and are low protein and low in complex carbohydrates and high in salt. Since most individuals and especially children and seniors do not meet the recommended intake of whole grains, green leafy vegetables and protein [7]. The development of whole grain gluten-free, high protein, vegetable snacks would help to meet such a need. Consumers need to be educated to desire healthy home cooking or health promoting commercially produced foods and snacks. There is a need to develop gluten-free whole grain nutritious tasty snacks. Such snacks could include health promoting spices as well.

Buckwheat is a pseudocereal, a low input crop with relatively high yields that can be grown in marginal lands. Its grain has unique triangular shape with size like wheat kernels. It contains no gluten that makes it suitable substitute grains for people who are sensitive to wheat or other grains that contain protein glu- 
tens. Top buckwheat production in thousand tons is Russia, 700; China, 662; Ukraine, 176; France, 111; US and Poland, 83 each [8]. One cup $155 \mathrm{~g}$ of buckwheat provides RDI of manganese $34 \%$, copper $28 \%$, magnesium $21 \%$, dietary fiber $18 \%$ and phosphorus $17 \%$.

Top peanut producing countries in million metric tons are China, 13.4; India, 7.7; United States, 1.9; Nigeria, 1.5; Indonesia, 1.1; Myanmar, 0.7; Chad and Senegal, 0.5 each; Ghana and Argentina, 0.4 each [8]. Peanuts produced in the U.S. are mostly used in food and confection products, but more than 50 percent of the world production is crushed for its oil. World production of peanuts is 30.5 million metric tons per year. Nearly 15 million tons of peanuts are used to extract oil resulting in 7.5 million tons of peanut meal. Peanut meal is low value byproduct mainly used as animal feed. This agricultural byproduct could be used to make high protein nutritious foods and snacks resulting in significant value addition to peanut growers.

Curly Kale is popular cruciferous green leafy vegetable rich in lutein, sulforaphhane, various flavonoids and polyphenols [9]. Steam cooked kale retains more of its nutrients and binds significantly more bile acids than raw [10]. Binding bile acids results in reduced fat absorption with potential to lower cholesterol. Sulphoraphane has been associated with reducing the risk of cancer [11]. A single cup of kale (67 g) provides RDA of vitamin C 134\%, vitamin A $206 \%$ and vitamin $\mathrm{K} 684 \%$.

Garlic (Allium sativum) is a widely used spice. In 2014 world production of garlic was 25 million tons. Top garlic producers in million tons are: China, 20.0; India, 1.25; South Korea, 0.35; Egypt and Russia 0.26 each [8]. Sharp flavor and taste of garlic is due to allicin, a sulfur containing compound. Garlic contains several phytonutrients with potential health benefits [12] [13].

Onion (Allium cepa), is a vegetable and is most widely cultivated spice. World production of onion in 2014 was 88.5 million tons. Top producers in million tons are: China 22.5; India, 19.4; USA, 3.2; Egypt 2.5; Iran, 2.1 and Russia 2.0 [8]. Phytonutrients and polyphenols of onion have health promoting potential [14].

Ginger (Zingiber officinale), is a common spice used in various cuisines and have been associated with various health benefits. Thomson et al. [15] reported that ginger could be used as a cholesterol-lowering, antithrombotic and anti-inflammatory agent. Addition of $4 \%$ ginger prevented the effect of hypertension inducing drug in rats [16] [17].

These snacks would be whole grain, gluten-free, high protein, vegetable, low in salt and calories and could be prepared in any home and/or by commercial food companies. In the study reported herein, sixty-nine in house volunteers evaluated four kinds of snacks containing gluten-free ancient whole grain Buckwheat (B), Peanut meal (P) and Kale (K). The snacks were BPK, BPK-Garlic, BPK-Onion and BPK-Ginger.

Practical Application: Ancient whole grain gluten-free Buckwheat, high protein Peanut meal and vegetable snacks were developed. Acceptance of Buck- 
wheat-Peanut Meal-Kale (BPK) and BKP-Garlic snacks was 94\%, BPK-Onion $86 \%$ and BKP-Ginger 78\%. These snacks were 25\% protein, 3.6 - 4.2 expansion and $72 \%-75 \%$ porosity. These snacks could be made in any house hold and/or commercial production. These healthy nutritious tasty snacks offer choice for all consumers, including individual's sensitive to gluten.

\section{Materials and Methods}

Whole grain buckwheat, raw peanuts, curly kale (fresh), dry powder (garlic, onion and ginger) were obtained from local grocery markets. Buckwheat flour was prepared by using Blendtec Kitchen Mill Model 91 at medium setting (Blendtec Inc., Wichita, Kansas, USA). Peanut meal was obtained by extracting oil using Vevor Oil Press (Joyfay.com, Cleveland, Ohio, USA). Kale was chopped using Mini-Prep Processor (Cuisinart.com, East Windsor, New Jersey, USA).

Ingredients and snacks were analyzed for nitrogen using AOAC method 990.03 [18] by Leco FP628 analyzer (LecoCorporation, StJoseph, MI, USA); crude fat with petroleum ether by accelerated solvent extractor (ASE350, Dionex Corp., Sunnyvale, CA, USA); ash, using AOAC method 942.05 [19]; and moisture, using AOAC method 935.29 [19]. Composition of buckwheat flour, peanut meal and kale is given in Table 1.

Dough Composition of Ancient Whole Grain Buckwheat (B), Peanut Meal (P) and Kale (K) Snacks is given in Table 2.

The snacks contained 23\% - 24\% Buckwheat, 23\% - 24\% Peanut Meal, 46\% -48\%

Table 1. Composition of buckwheat, peanut meal and kale, dry matter basis $\%$.

\begin{tabular}{cccccc}
\hline Ingredients & Protein & Fat & Minerals & Carbohydrates & DM \\
\hline Buckwheat & $16.30 \pm 0.12$ & $3.33 \pm 0.12$ & $2.97 \pm 0.01$ & $66.81 \pm 0.15$ & $89.41 \pm 0.11$ \\
Peanut meal & $59.69 \pm 0.50$ & $15.96 \pm 0.15$ & $3.94 \pm 0.05$ & $14.31 \pm 0.25$ & $93.90 \pm 0.02$ \\
Kale & $2.01 \pm 0.01$ & $0.90 \pm 0.00$ & $1.88 \pm 0.00$ & $9.00 \pm 0.01$ & $13.79 \pm 0.07$ \\
\hline
\end{tabular}

Nitrogen to protein factors used was 6.25. Dry matter, DM. Carbohydrate $=[$ Dry matter $-($ Protein + Fat + Ash)]. Samples were analyzed in triplicates. Values are mean \pm SEM.

Table 2. Dough composition of ancient whole grain gluten-free buckwheat (B), peanut meal $(\mathrm{P})$ and kale $(\mathrm{K})$ snacks, as is basis \%.

\begin{tabular}{|c|c|c|c|c|c|c|c|c|c|}
\hline Snack & B & $\mathrm{p}$ & $\mathrm{k}$ & Oil & Salt & Garlic & Onion & Ginger & Water \\
\hline BPK & 23.8 & 23.8 & 47.6 & 3.6 & 1.2 & & & & $100 \mathrm{ml}$ \\
\hline BPK-Garlic & 22.9 & 22.9 & 45.7 & 3.4 & 1.1 & 4.0 & & & $120 \mathrm{ml}$ \\
\hline BPK-Onion & 23.2 & 23.2 & 46.3 & 3.5 & 1.2 & & 2.7 & & $120 \mathrm{ml}$ \\
\hline BPK-Ginger & 23.2 & 23.2 & 46.3 & 3.5 & 1.2 & & & 2.7 & $120 \mathrm{ml}$ \\
\hline
\end{tabular}

Level of Garlic, Onion and Ginger was decided by consensus of laboratory personnel. 
fresh Curly Kale, 3\% - 4\% Peanut Oil, 1.1\% - 1.2\% salt. Garlic snacks contained $4 \%$ dry Garlic powder and Onion and Ginger snacks contained 2.7\% dry Onion or Ginger powder. Snacks dough was prepared by adding $100-120 \mathrm{~mL}$ water to $100 \mathrm{~g}$ of as is ingredients. Dough was set at room temperature for $30 \mathrm{~min}$. The levels of garlic, onion and ginger were decided by the consensus of laboratory personnel. Snacks were cooked in a 1050-Watt, Chef's Choice KrumKake Express 839 (Edge Craft Corporation, Avondale, PA, USA). KrumKake Express with heat control dial settings 1-6 was heated at setting 4 till green ready light turned on. Baking temperature ranged from $185^{\circ} \mathrm{C}-208^{\circ} \mathrm{C}$ as measured by Anritsu Meter AP-710 (Anritsumeter Co., Tokyo, Japan). Cooking surface was lightly greased and $20 \mathrm{~g}$ snack dough was placed on the center of heated KrumKake Express baker and cooked for 2 min. Figure 1 shows four kinds of gluten-free ancient whole grain Buckwheat-Peanut Meal-Kale cooked snacks. Cooked snacks were cooled to room temperature then vacuum heat sealed in plastic bags by Food Saver 2200 Series (Foodsaver.com, Boca Raton, FL, USA).

\subsection{Sensory Evaluation of Snacks}

Vacuum packed cooked snacks were opened and cut into four pieces with a pizza cutter. All four kinds of snacks were placed in an eight inch by ten-inch plate labeled Buckwheat-Peanut Meal-Kale (BPK), BPK-Garlic, BPK-Onion, BPK-Ginger Figure 2. Sixty-nine in-house volunteers tasted the snacks in four

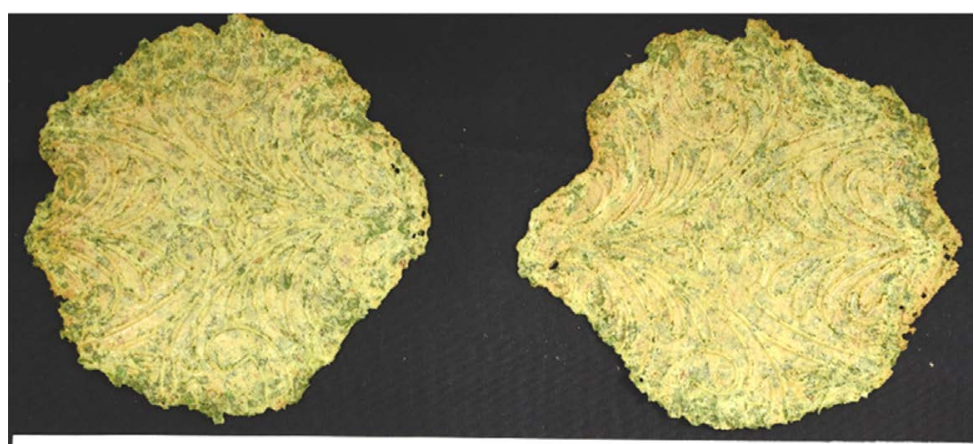

Buckwheat-Peanut Meal-Kale (BPK)

BPK-Garlic

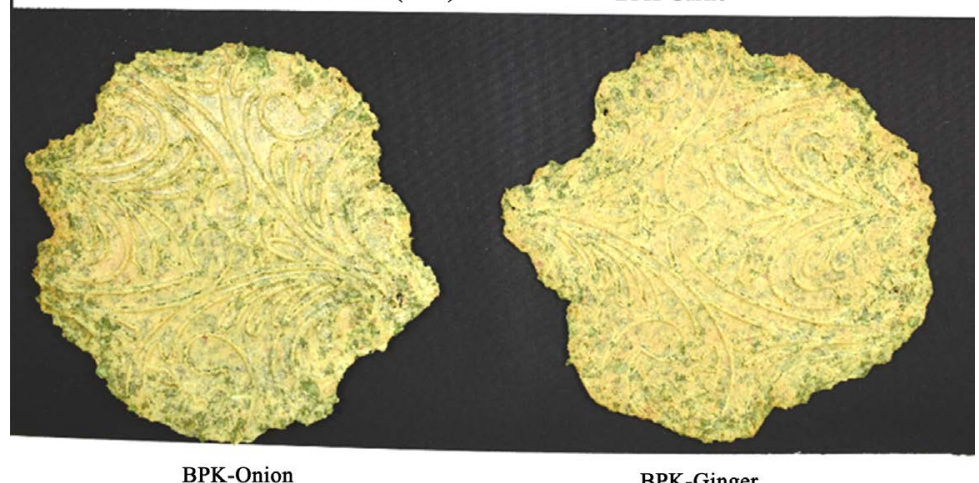

BPK-Ginger

Figure 1. Buckwheat-Peanut Meal-Kale (BPK), BPK-Garlic, BPK-Onion and BPK-Ginger cooked snacks. 


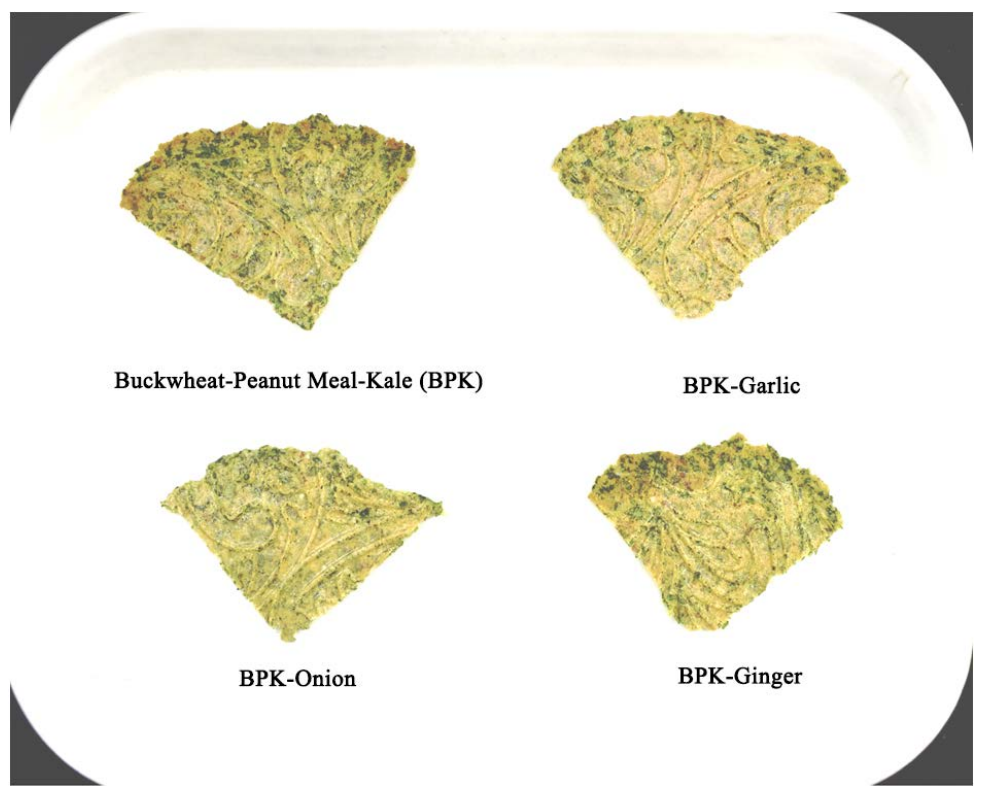

Figure 2. Four kinds of buckwheat whole grains high protein kale snacks as offered for sensory evaluation to the tasters. Top left: Buckwheat-Peanut Meal-Kale (BPK); Top right: BPK-Garlic; Bottom left: BPK-Onion; Bottom right: BPK-Ginger.

sensory evaluation booths under white light for Color/Appearance, Odor/Aroma, Taste/Flavor, Texture/Mouth-feel and Acceptance. Snacks were evaluated individually and not for relative rating. The sensory parameters were evaluated on a scale of $1-5$ (Like very much $=5$, like slightly $=4$, neutral $=3$, dislike slightly $=$ 2 and dislike very much $=1$ ); Acceptance was evaluated on a scale of $1-2$ (Acceptable $=2$ and unacceptable $=1$ ).

\subsection{Water Activity}

Water activity (Aw) of Buckwheat-Peanut Meal-Kale gluten-free whole grains snacks were measured at $25.01^{\circ} \mathrm{C} \pm 0.02^{\circ} \mathrm{C}$ in triplicate using an Aqua Lab $4 \mathrm{TE}$ dew point water activity meter (Decagon Devices, Inc., Pullman, WA, USA).

\subsection{Density}

The bulk density $(\rho b)$ of BPK gluten-free whole grain snacks was measured by Ottawa Sand volume displacement of $10 \mathrm{~g}$ sample in triplicate after shaking in a jar of 202 CC volume. The first reading was taken after shaking for $15 \mathrm{~min}$., subsequent two readings were taken after additional shaking for 5 min each time. True density $(\rho t)$ was determined five times using gas displacement pycnometer AccuPycII1340 (Micromeritics Instrument Co., Norcross, GA, USA) at $21.4^{\circ} \mathrm{C} \pm 0.4^{\circ} \mathrm{C}$. Samples of each snack were dried in triplicate at room temperature for $15 \mathrm{hr}$ at $0 \%$ relative humidity in a vacuum desiccator with anhydrous calcium sulfate (W.A. Hammond Drierite, Xenia, OH, USA). After drying, small pieces of samples were compressed into a density measuring cylinder of the pycnometer and five true density values were recorded. 


\section{Statistical Analysis}

Data were analyzed with Mini tab software (version14.12.0, Minitab inc., State College, PA, USA) using one-way analysis of variance and Tuckey's multiple comparison tests with $(p \leq 0.05)$ was considered the criterion of significance.

\section{Results and Discussion}

Color/Appearance and Texture/Mouth feel of Buckwheat-Peanut Meal-Kale (BPK), BPK-Garlic, BPK-Onion and BPK-Ginger were judged to be similar by sensory evaluation by 69 in-house volunteer tasters (Table 3 ).

Odor/Aroma for BPK-Garlic snacks was significantly $(p \leq 0.05)$ better than that for BPK-Ginger snacks. Taste/Flavor for BPK, BPK-Garlic and BPK-Onion snacks were similar and significantly higher than for BPK-Ginger snacks. Data suggests that Taste/Flavor of BPK, BPK-Garlic and BPK-Onion snacks was preferred compared with BPK-Ginger snacks. Acceptance of BPK-Onion snacks was similar to the other three kinds of snacks tested. Acceptance for BPK and BPK-Garlic snacks was similar and significantly higher than BPK-Ginger snacks.

Desirability index for sensory parameters was calculated as percent of tasters judged [like very much + like slightly + 1/2 (neutral)] [20] [21]. Desirability index for BPK, BPK-Garlic, BPK-Onion and BPK-Ginger snacks for Color/Appearance 85\%, 84\%, 76\% and 79\%; Odor/Aroma 81\%, 83\%, 79\% and $72 \%$; Taste/Flavor $86 \%, 78 \%$, 80\% and 59\%; Texture/Mouth feel 96\%, 95\%, 96\% and $93 \%$, respectively. Desirability index for the ancient whole grain, gluten-free, high protein, vegetable, snacks values ranged from $72 \%-96 \%$ that would be considered very encouraging, except for BPK-Ginger snacks with Taste/Flavor value was only 59\%. Data suggest that ginger flavor was less favored.

Percent acceptance of ancient whole grain gluten-free Buckwheat-Peanut Meal-Kale snacks is given in Figure 3. Acceptance of BPK and BPK-Garlic snacks was similar and significantly higher than BPK-Ginger snacks. Percent acceptance values ranged from 78\% - 94\%. Acceptance values for the whole grain gluten-free high protein vegetable snacks tested were very desirable.

Table 3. Results of taste panel of Buckwheat-Peanut Meal-Kale (BPK) whole grain, gluten-free, high protein vegetable snacks ${ }^{\mathrm{ab}}$.

\begin{tabular}{cccccc}
\hline Snack & $\begin{array}{c}\text { Color } \\
\text { Appearance }\end{array}$ & $\begin{array}{c}\text { Odor } \\
\text { Aroma }\end{array}$ & $\begin{array}{c}\text { Taste } \\
\text { Flavor }\end{array}$ & $\begin{array}{c}\text { Texture } \\
\text { Mouth feel }\end{array}$ & Acceptance \\
\hline BPK & $3.98 \pm 0.10 \mathrm{a}$ & $3.78 \pm 0.10 \mathrm{ab}$ & $3.96 \pm 0.10 \mathrm{a}$ & $4.42 \pm 0.08 \mathrm{a}$ & $1.94 \pm 0.03 \mathrm{a}$ \\
BPK-Garlic & $3.83 \pm 0.11 \mathrm{a}$ & $3.90 \pm 0.10 \mathrm{a}$ & $4.03 \pm 0.14 \mathrm{a}$ & $4.38 \pm 0.08 \mathrm{a}$ & $1.94 \pm 0.03 \mathrm{a}$ \\
BPK-Onion & $3.75 \pm 0.11 \mathrm{a}$ & $3.78 \pm 0.10 \mathrm{ab}$ & $3.99 \pm 0.13 \mathrm{a}$ & $4.39 \pm 0.09 \mathrm{a}$ & $1.86 \pm 0.04 \mathrm{ab}$ \\
& & & & & \\
BPK-Ginger & $3.78 \pm 0.11 \mathrm{a}$ & $3.58 \pm 0.09 \mathrm{~b}$ & $3.30 \pm 0.14 \mathrm{~b}$ & $4.28 \pm 0.08 \mathrm{a}$ & $1.78 \pm 0.05 \mathrm{~b}$ \\
\hline
\end{tabular}

${ }^{\mathrm{a}}$ Values (mean \pm SEM) within columns with different letters differ significantly $(p \leq 0.05), \mathrm{n}=69$. ${ }^{\mathrm{b}}$ Sensory evaluation parameters were on a scale of $1-5$ (Like very much $=5$, like slightly $=4$, neutral $=3$, dislike slightly $=2$ and dislike very much $=1$ ); Acceptance was on scale of $1-2$ (Acceptable $=2$ and unacceptable $=$ 1). 


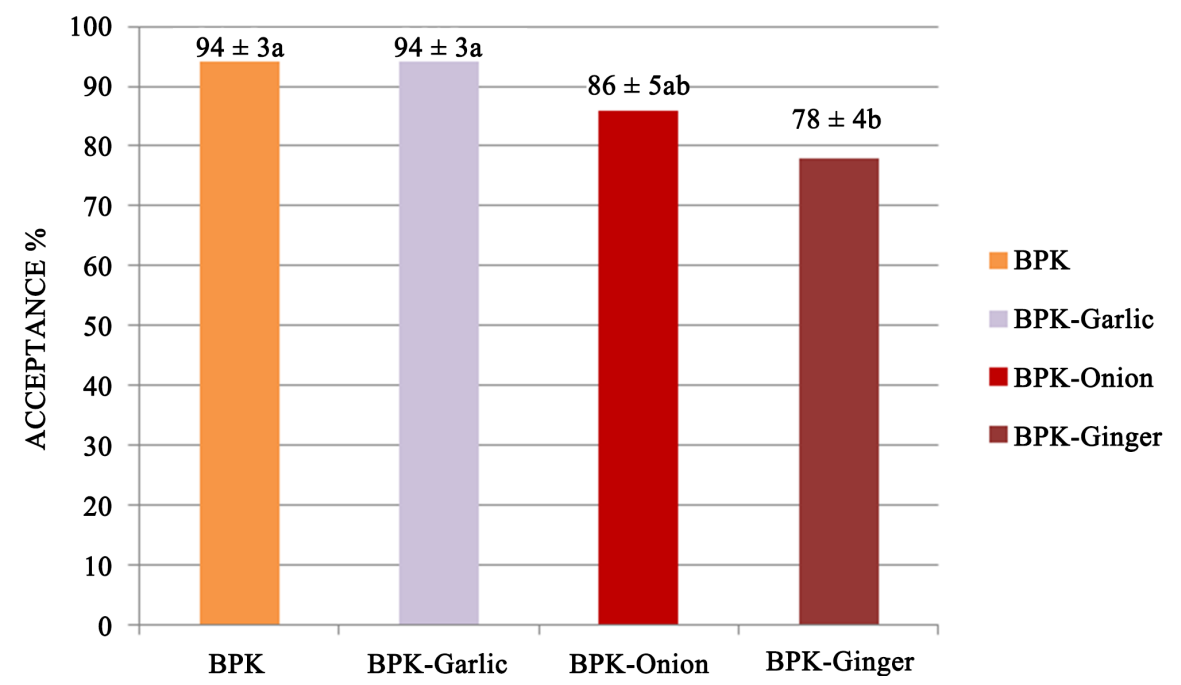

Figure 3. Percent acceptance (Y-axis = acceptance \%) (mean \pm SEM). Buckwheat-Peanut Meal-Kale (BPK), BPK-Garlic, BPK-Onion and BPK-Garlic snacks $(\mathrm{n}=69)$. Values with different letters differ significantly $(p \leq 0.05)$.

Water activity of BPK and BPK-Onion snacks was significantly lower than that for BPK-Garlic and BPK-Ginger snacks (Table 4). Relative water activity of the snacks tested was BPK-Ginger $=$ BPK-Garlic $>$ BPK $=$ BPK-Onion. Water activity values ranged from $0.35-0.38$. Data suggest that BPK and BPK-Onion snacks were crunchier with higher antimicrobial stability. Carrots snacks with Aw of 0.44 were reported to have desired crispness and antimicrobial stability [22] [23].

True density $(\rho t)$ values for the whole grain, high protein vegetable snacks tested ranged from 1.35 - 1.37. Differences among snacks tested were BPK-Onion $>$ BPK $=$ BPK-Garlic $>$ BPK-Ginger. Bulk density $(\rho b)$ values for $\mathrm{BPK}, \mathrm{BPK}-$ Onion and BPK-Ginger were similar and significantly higher than BPK-Garlic snacks. Porosity of BPK-Garlic snacks was significantly higher than BPK, BPK-Onion and BPK-ginger snacks. Expansion of BPK-Garlic snacks was significantly higher than the other snacks tested. Expansion values for BPK-Onion snacks were also significantly higher than BPK and BPK-Ginger snacks. Expansion values were BPK-Garlic $>$ BPK-Onion $>$ BPK $=$ BPK-Ginger. Expansion values ranged from 3.6 to 4.2 with high $72 \%-75 \%$ porosity suggests that these snacks quite light and brittle and would be quite filling and would give desirable presentation in their packaging.

Composition of ancient whole grain, gluten-free, high protein, vegetable snacks is given in (Table 5). The protein content of the formulated snacks ranged from $25 \%-29 \%$. The aim was to achieve $25 \%$ protein snacks and add value to peanut meal. This object was clearly achieved. The peanut oil extracted by compressors without the use of organic chemicals would be desirable with higher market price. Food grade peanut meal with its use in high protein healthy snacks would add value to this farm byproduct. Most common snacks on the market are high salt with only $2 \%-10 \%$ protein. The fat content of these snacks 
Table 4. Water activity (Aw), true density ( $\rho$ t), bulk density $(\rho b)$, porosity and expansion of Buckwheat-Peanut Meal-Kale (BPK) whole grain, gluten-free, high protein snacks.

\begin{tabular}{cccccc}
\hline Snack & Aw & $\rho t$ & $\rho \mathrm{b}$ & Porosity & Expansion \\
\hline BPK & $0.35 \pm 0.10 \mathrm{~b}$ & $1.36 \pm 0.01 \mathrm{~b}$ & $0.38 \pm 0.10 \mathrm{a}$ & $0.72 \pm 0.01 \mathrm{~b}$ & $3.6 \pm 0.03 \mathrm{c}$ \\
BPK-Garlic & $0.37 \pm 0.11 \mathrm{a}$ & $1.36 \pm 0.01 \mathrm{~b}$ & $0.33 \pm 0.14 \mathrm{~b}$ & $0.75 \pm 0.01 \mathrm{a}$ & $4.2 \pm 0.03 \mathrm{a}$ \\
BPK-Onion & $0.35 \pm 0.11 \mathrm{~b}$ & $1.37 \pm 0.01 \mathrm{a}$ & $0.37 \pm 0.13 \mathrm{a}$ & $0.73 \pm 0.01 \mathrm{~b}$ & $3.8 \pm 0.04 \mathrm{~b}$ \\
BPK-Ginger & $0.38 \pm 0.11 \mathrm{a}$ & $1.35 \pm 0.01 \mathrm{c}$ & $0.37 \pm 0.14 \mathrm{a}$ & $0.72 \pm 0.01 \mathrm{~b}$ & $3.6 \pm 0.05 \mathrm{c}$ \\
\hline
\end{tabular}

Values (mean \pm SEM) within columns with different letters differ significantly $(p \leq 0.05), \mathrm{n}=69$. Water activity (Aw) was measured $(\mathrm{N}=3)$ at $25.01^{\circ} \mathrm{C} \pm 0.02^{\circ} \mathrm{C}$ by AquaLab dew point water activity meter $4 \mathrm{TE}$ (Decagon Devices, Inc., Pullman, WA). True density ( $\rho t)$ was determined $(\mathrm{N}=5)$ by AccPyc II 1340 gas pycnometer (Micromeritics Instrument Co., Norcross, GA) at $21.4^{\circ} \mathrm{C} \pm 0.4^{\circ} \mathrm{C}$. The bulk density ( $\mathrm{pb}$ ) of each sample was measured $(\mathrm{N}=3)$ by Ottawa Sand volume displacement by about $10 \mathrm{~g}$ of sample in triplicate after 15-5-5 minutes shaking in a jar of $202 \mathrm{cc}$ volume. Porosity was calculated using the equation $[$ Porosity $=1-(\rho \mathrm{b} / \rho t)]$. Expansion was calculated using the equation $[$ Expansion $=(\rho t / \rho b)]$.

Table 5. Composition of Buckwheat-Peanut Meal-Kale (BPK) whole grain, gluten-free, high protein snacks.

\begin{tabular}{cccccc}
\hline Snack & Protein & Fat & Minerals & Carbohydrates & DM \\
\hline BPK & $28.67 \pm 1.74$ & $15.93 \pm 0.04$ & $6.12 \pm 0.01$ & 39.62 & $91.34 \pm 0.01$ \\
BPK-Garlic & $25.37 \pm 0.41$ & $14.77 \pm 0.11$ & $6.06 \pm 0.01$ & 46.14 & $92.34 \pm 0.01$ \\
BPK-Onion & $25.96 \pm 1.58$ & $16.08 \pm 0.13$ & $6.15 \pm 0.01$ & 43.93 & $92.12 \pm 0.05$ \\
BPK-Ginger & $27.53 \pm 1.39$ & $14.09 \pm 0.04$ & $6.13 \pm 0.01$ & 43.94 & $91.69 \pm 0.02$ \\
\hline
\end{tabular}

Nitrogen to protein factors used was 6.25. Dry matter, DM. Carbohydrate $=[$ Dry Matter $-($ Protein + Fat + Ash)]. Samples were analyzed in triplicates. Values are mean \pm SEM, $(n=3)$.

ranged $14 \%-16 \%$. In the subsequent snack formulations effort would be made to even lower their fat content while maintaining the desirable sensory parameters. Mineral content of the four kinds of snacks tested ranged from $6.06 \%$ $6.15 \%$. Since these snacks contained only $1.1 \%-1.2 \%$ salt. These snacks would be considered low sodium and good source of other essential minerals.

\section{Conclusion}

Four kinds of ancient whole grain gluten-free high protein vegetable snacks were evaluated by sixty-nine in-house volunteers. The object was successfully attained to formulate $25 \%$ protein gluten-free whole grain vegetable snacks. Protein content of the snacks tested ranged from $25 \%-29 \%$. It has added value to peanut meal a farm byproduct mainly used as animal feed. Acceptance of BuckwheatPeanut Meal-Kale (BPK) and BKP-Garlic snacks was $94 \%$, BPK-Onion $86 \%$ and BKP-Ginger $78 \%$. These acceptance values are very desirable. These snacks are formulated using only 3 - 4 ingredients and could be made in any house hold on counter top appliances and in commercial productions. The water activity of these snacks ranged 0.35 - 0.38 suggesting that the snacks were crispy with good antimicrobial stability. Expansion of the cooked snacks was 3.6 - 4.2 with high $72 \%-75 \%$ porosity suggesting that these snacks would light and brittle and would 
be quite filling with desirable presentation in commercial packaging. These whole grain gluten-free high protein vegetable healthy nutritious tasty snacks offer choice for all consumers, including individual's sensitive to gluten.

\section{Acknowledgements}

The authors sincerely thank all the sensory evaluators of this study.

\section{Conflict of Interest Declaration}

All the authors of this manuscript have no conflict of interest with its contents or statements.

\section{References}

[1] Prepared Foods (2016) http://www.preparedfoods.com/articles/118054

[2] USDA (2015) Nutrition Policy and Promotion; Dietary Guidelines for Americans. http://health.gov/dietaryguidelines/2015/guidelines/

[3] Whole Grain Council (2009) http://www.wholegrainscouncil.org/

[4] Halnaes, A., Kyro, C., Anderson, I., Lacoppidan, S., Overvad, K., Christensen, J., Tjonneland, A. and Olsen, A. (2016) Intake of Whole Grains Is Associated with Lower Risk of Myocardial Infarction: The Danish Diet, Cancer and Health Cohort. The American Journal of Clinical Nutrition, 103, 999-1007. https://doi.org/10.3945/ajcn.115.124271

[5] Lebwohl, B., Ludvigsson, J.F. and Green, P.H. (2015) Celiac Disease and Non-Celiac Gluten Sensitivity. BMJ (Review), 351, h4347.

[6] Food and Drug Administration Defines Gluten-Free (2014). https://www.fda.gov/ForConsumers/ConsumerUpdates/ucm363069.htm

[7] Mother-Jones (2017) No, Feeding Hungry Kids and Seniors Isn't a Waste of Money. www.motherjones.com/politics/2017/03/trump-budget-school-meals-on-wheels/

[8] UN Food \& Agriculture (FAO) (2014) Production of Crops by Countries. http://www.fao.org/traditional-crops/

[9] Angeloni, C., Leoncini, E., Malaguti, M., Angelini, S., Hrelia, P. and Hrelia, S. (2009) Modulation of Phase II Enzymes by Sulforaphane: Implications for Its Cardioprotective Potential. Journal of Agricultural and Food Chemistry, 57, 615-622. https://doi.org/10.1021/jf900549c

[10] Kahlon, T.S., Chiu, M.M. and Chapman, M.H. (2008) Steam Cooking Significantly Improves in vitro Bile Acid Binding of Collard Greens, Kale, Mustard Greens, Broccoli, Green Bell Pepper, and Cabbage. Nutrition Research, 28, 351-357. https://doi.org/10.1016/j.nutres.2008.03.007

[11] Amjad, A.I., Parikh, R.A., Appleman, L.J., Hahm, E.R., Singh, K. and Singh, S.V. (2015) Broccoli-Derived Sulforaphane and Chemoprevention of Prostate Cancer: from Bench to Bedside. Current Pharmacology Reports, 1, 382-390. https://doi.org/10.1007/s40495-015-0034-x

[12] Rahman, K. (2007) Effects of Garlic on Platelet Biochemistry and Physiology. Molecular Nutrition \& Food Research, 51, 1335-1344.

[13] Guercio, V., Turati, F., La Vecchia, C., Galeone, C. and Tavani, A. (2016) Allium Vegetables and Upper Aerodigestive Tract Cancers: A Meta-Analysis of Observational Studies. Molecular Nutrition \& Food Research, 60, 212-222. 
https://doi.org/10.1002/mnfr.201500587

[14] Slimestad, R., Fossen, T. and Vågen, I.M. (2007) Onions: A Source of Unique Dietary Flavonoids. Journal of Agricultural and Food Chemistry, 55, 10067-10080. https://doi.org/10.1021/jf0712503

[15] Thomson, M., Al-Qattan, K.K., Al-Sawan, S.M., Alnaqeeb, M.A., Khan, I. and Ali, M. (2002) The Use of Ginger (Zingiber officinale Rosc.) as a Potential Anti-Inflammatory and Antithrombotic Agent. Prostaglandins, Leukotrienes and Essential Fatty Acids, 67, 475-478. https://doi.org/10.1054/plef.2002.0441

[16] Akinyemi, A.J., Thomé, G.R., Morsch, V.M., Bottari, N.B., Baldissarelli, J., Oliveira, L.S., Goularte, J.F., Belló-Klein, A., Oboh, G. and Schetinger, M.R. (2016) Dietary Supplementation of Ginger and Turmeric Rhizomes Modulates Platelets Ectonucleotidase and Adenosine Deaminase Activities in Normotensive and Hypertensive Rats. Phytotherapy Research, 30, 1156-1163. https://doi.org/10.1002/ptr.5621

[17] Ahmad, B., Rehman, M.U., Insha, A., Arif, A., Rasool, S., Bhat, S.A., Insha, A.I., Ishraq, H.I., Bilal, S. and Mir, M.U. (2015) A Review on Pharmacological Properties of Zingerone (4-(4-Hydroxy-3-methoxyphenyl)-2-butanone). The Scientific World Journal, 2015, Article ID: 816364. https://doi.org/10.1155/2015/816364

[18] AOAC (2000) Official Methods of Analysis of the Association of Official Analytical Chemists. 17th Edition, The Association, Arlington.

[19] AOAC (1990) Official Methods of Analysis of the Association of Official Analytical Chemists. 15th Edition, The Association, Arlington.

[20] Kahlon, T.S., Milczarek, R.R. and Chiu, M.M. (2013) Whole Grain Gluten-Free Egg-Free Pasta. Cereal Foods World, 58, 4-7. https://doi.org/10.1094/CFW-58-1-0004

[21] Kahlon, T.S., Milczarek, R.R. and Chiu, M.M. (2013) Whole Grain Gluten-Free Egg-Free High Protein Pasta. Vegetos, 26, 65-71. https://doi.org/10.5958/j.2229-4473.26.2.055

[22] Adams, M.R. and Moss, M.O. (1997) Food Microbiology. The Royal Society of Chemistry, Cambridge.

[23] Dueik, V., Marzullo, C. and Bouchon, P. (2013) Effect of Vacuum Inclusion on the Quality and the Sensory Attributes of Carrot Snacks. Food Science and Technology, 50, 361-365. 